\title{
FACTORS AFFECTING FARMER MOTIVATION IN REQUESTING DUCK FARM CREDIT: A CASE STUDY IN CIREBON, WEST JAVA, INDONESIA
}

\author{
A. Saleh and R.W. Lumintang \\ Department of Communication and Community Development Sciences, \\ Faculty of Human Ecology, Bogor Agricultural University, \\ Jl. Kamper, Darmaga Campus, Bogor 16680 - Indonesia \\ Corresponding E-mail: amiruddin_ipb@yahoo.co.id
}

Received November 9, 2011; Accepted April 22, 2012

\begin{abstract}
ABSTRAK
Tujuan penelitian adalah untuk mengidentifikasi dan menganalisis motivasi peternak dalam mengambil paket kredit usaha peternakan itik berdasarkan karakteristik dan perilaku komunikasi peternak. Sampel dipilih di antara peternak itik di desa Kroya Cirebon. Faktor-faktor karakteristik personal adalah usia, jenis usaha (sambilan/pokok), skala usaha ternak, pengalaman, pendidikan, dan pendapatan. Adapun aspek-aspek perilaku komunikasi dilihat dari intensitas berkomunikasi dengan penyuluh, ketua kelompok, sesama peternak, atau dengan petugas kredit, dan keikutsertaan peternak dalam organisasi kemasyarakatan. Motivasi peternak mengambil paket kredit dipengaruhi oleh karakteristik peternak, seperti tingkat pendidikan, pendapatan dan usia. Perilaku komunikasi peternak yang semakin sering dikunjungi penyuluh, dikunjungi dan mengunjungi petugas pemberi kredit, serta semakin aktif ikutserta dalam organisasi kemasyarakatan mempunyai motivasi yang semakin tinggi dalam mengambil kredit, daripada karakteristik personal peternak. Aktivitas komunikasi dapat digunakan untuk membujuk peternak dalam mengambil kredit.
\end{abstract}

Kata kunci: itik, komunikasi, kredit usaha, peternak, penyuluh

\begin{abstract}
Objectives of study was to observe and to analyze the farmer motivation in requesting farmer credit (bank loan) for duck, based on farmer characteristics and communication behavior. Sample was chosen among duck farmers in Kroya village, Cirebon. Characteristic factors were: age, part-timer farmer, farm size, experience, education, and income. While the communication behavior factors were communicating with extension worker or credit officer, and participating in social problems. Farmer motivation to apply credit impacted by their characteristics, such as educational level, income and age. Communication behavior, such as participating in extension activities and social organization,were more impacted to apply credit, than farmer characteristics. Communication activities can be used to persuade farmer to apply credit.

Keywords: extension worker, communication, duck, farmer, credit
\end{abstract}

\section{INTRODUCTION}

Duck farm development in Indonesia supports an important role to be an alternative income source among the farmer community in rural area. Cirebon was one of potential area for growing duck farm business. With the passing time, the pressure of growing duck farm business, and low of capital retaining rate, represented a business demand for duck farm investment. Credit, as a reliable source of working capital, represented against 'warranty substitutes' such as reputation in the community, group guarantees or compulsory savings (Lakin and Scheubel, 2010). Credit as a microfinance services, should provide options to minimize poverty among the farmer lives, and to invest in income generating activities with risk levels appropriate to the household basic needs security (Oakley, 1988). Main disputes in particular business cope with some restrictions, such as capital owning. Overcoming the particular constraint, the government accommodates to launch a credit facility.

Motivation was initiated and predisposeed individually to gain something, especially 
knowledge (Kamhawi and Weaver, 2003; Leeuwis, 2004). Farmer motivation in requesting credit becomes a requirement for government to launch the duck farm credit program. Sah and Gardner (2008) mentioned motive consisted of cognitive, diversified, and identity personal oriented. Cognitive oriented included the need of information and knowledge. Diversified oriented was a need for entertainment. Identity personal was closed related to individual characteristics. Motive in this study was concentrated to the two main factors: characteristics and social problems as an orientation to work at information.

Consequently the study was concentrated on the factors attaining farmer motivation in requesting duck farm credit, entailed of two main factors: farmer characteristics and communication behavior.

\section{MATERIALS AND METHODS}

Research was conducted in Kroya village, Cirebon, where duck farms were most populated from large to small size (Ministry of Agriculture, 2006). The sample of 40 duck farmers were selected randomly from population of duck farmer. The instrument was reviewed for content validity by a panel of experts (Lindner et al., 2001). Reliability of the instrument was tested by Cronbach's alpha coefficient for each variable (Cronbach, 1951). A reliability level of 0.80 or higher was considered acceptable (van den Ban, 1988).

Questioner's survey was managed by interviewing. Matrix correlation statistical test was employed to analyze. Age measured by year. Educational level was measured by schooling year. Occupation was measured by farmer vs non farmer. Size of business was measured by total duck owned. Experience was measured by total farming year. Income was measured by total capital owned (IDR) .

Communication behaviour was measured by total frequency of communicating. Farmer motivation was measured by total score of ranking. Theoretical framework of the study was: Farmer characteristics $\left(\mathrm{X}_{1}\right)$ consisted of: age, educational level, occupation, size of business, experience in duck business, and income; Communication behavior $\left(\mathrm{X}_{2}\right)$, consisted of communicating interactive and involved with social problems; influence toward $(\mathrm{Y})$ farmer motivation in requesting farm credit.

\section{RESULTS AND DISCUSSION}

\section{Village Description}

Kroya was located in Kapetakan district, Cirebon, lies in $139 \mathrm{~km}$ away from Bandung, the capital of West Java Province. It lies $8 \mathrm{~km}$ away from capital of district. The width of paddy rice was 178.5 ha, where the duck farm runs as parttimer job. Farmer population was 1,093 out of total population 3,172 people (Statistik Desa, 2006). Duck farm business was categorized in three groups: (1) breeding farm, (2) rearing farm, and (3) layer farm. Most of the farm was run as a family business, means most of labor was family member.

Duck farm credit amounted from IDR 750,000 to $1,500,000$ per credit unit was realized by the Bank Rakyat Indonesia (BRI). Most of the farmer requesting credit through farmer group and cooperative. Extension worker and credit officer were merely giving information to farmer.

\section{Farmer Characteristics Affecting Motivation}

Farmer motivation was supervised by extension worker. It constitutes a primary effort to inquire credit among the farmers. Sah and Gardner (2008) defined the motivation as a cycling process consist of three aspects: (1) Motive, (2) Objective, and (3) Instrumental behavior. Motive was induced by objective and creates an instrumentally behavior. Result of study indicated that characteristics affected motive either positive or negative (Table 1).

Correlation analysis was treated to identify the statistically relationship between motivation and characteristics aspects. The correlation are presented in Table 2. Most of the respondent was younger (22-35 year old) and to be categorized as productive farmer. Age factor indicated the negative relationship, means that the younger farmers were much easier adopting new innovation, such as credit, and they tended to be more motivated to request credit than the elder farmer did.

Educational level was varied. Most of the respondent was primary school graduated $(45 \%)$. It was concluded that livestock farmer holds a lower educational level, and they tend to refuse adopting a new innovation. It mentioned that the higher educated farmer was more motivated to apply credit than the lower educated farmer did.

The main occupation of the respondent was diverse, although most of them engaged in duck farm activity (60\%). Main occupation factor 
Table 1. Correlation Coefficients Matrix of the Independent Variables and Farmer Motivation $(n=40)$

\begin{tabular}{cccccccc}
\hline Variables & $\mathrm{Y}$ & $\mathrm{X}_{1}$ & $\mathrm{X}_{2}$ & $\mathrm{X}_{3}$ & $\mathrm{X}_{4}$ & $\mathrm{X}_{5}$ & $\mathrm{X}_{6}$ \\
\hline $\mathrm{Y}$ & 1.000 & & & & & & \\
$\mathrm{X}_{1}$ & -0.017 & 1.000 & & & & & \\
$\mathrm{X}_{2}$ & 0.203 & -0.151 & 1.000 & & & & \\
$\mathrm{X}_{3}$ & -0.079 & -0.134 & $4.464^{*}$ & 1.000 & & & \\
$\mathrm{X}_{4}$ & 0.063 & -0.113 & 0.194 & 0.312 & 1.000 & & \\
$\mathrm{X}_{5}$ & 0.200 & 0.078 & -0.238 & -0.154 & 0.292 & 1.000 & \\
$\mathrm{X}_{6}$ & 0.155 & -0.169 & $4.662^{*}$ & 0.234 & 0.211 & -.0127 & 1.000 \\
* = significant at 0.05 level; $\mathrm{Y}=$ motivation; $\mathrm{X}_{1}=$ age; $\mathrm{X}_{2}=$ educational level; $\mathrm{X}_{3}=$ main occupation; $\mathrm{X}_{4}=$ \\
size of business; $\mathrm{X}_{5}=$ experience; $\mathrm{X}_{6}=$ income
\end{tabular}

Table 2 . Average of Farmer Characteristics $(\mathrm{n}=40)$

\begin{tabular}{ll}
\hline \multicolumn{1}{c}{ Characteristics } & \multicolumn{1}{c}{ Item } \\
\hline Age & $22-35$ year old \\
Educational level & Primary school \\
Occupation & Duck farmer \\
Size of business & 1.137 duck \\
Experience in duck farm & 9 years \\
Income & IDR 396,867. \\
\hline
\end{tabular}

mentioned the negative relationship to motive. It means that the part time duck farmer was more motivated to apply credit than the full time farmer did, because they need to develop their business as well. As the consequence, their business was needed to be supported in capital, such as credit.

Size of business refers to number of duck owned. Averaged number of duck owned was 1,137ducks, and most of the farmer owned duck was less than average. However, the circumstances indicated the bigger size of business, the more motivated to apply credit.

Experience as the accumulation of learning process to respond positively to a new innovation (Lee, 2005). Most of the farmer has experience in duck farm was around nine-year. Duck farm as full time job was newly developed recently. It denoted the more experienced the farmer, the more motiveded to apply the credit. Experienced farmer tended to recognize the benefit of the credit as an input to develop their business.

Traditionally, duck farm as a small business was typically indicated by income. Total income average was IDR 369,867 a month; was a circumstance that the farmer needed a capital loan to support their business. The higher the income, the highly motivated to apply credit. The higher income allowing the farmer to repay the credit. The higher income farmer were almost high school graduated, therefore they were really understood the procedure to apply credit.

Leeuwis (2004) indicated that a person decides whether to accept or refuse an innovation, was supported by motive. The other factors, such as habit, social prejudice, and entrepreneurial caution were included as a conservative attitude to prevent adoption any innovation, eventhough the most advanced techniques. Result of study mentioned, such situations were happened in duck farm.

Communication problems occured among the farmer in applying farm credit. Harris and Nelson (2008) defined a problem was a mutual assignment of meaning and simultaneous responses by all person. Communication will be effective, as complex, dynamic, irreversible, contextual and simultaneous understanding. Providing information and problem solving will grow personally characteristic acurately (Burgoon and Le Poire, 1993), and also growing selfenhancement as a product of motive (Lakin and Schaubel, 2010). 
Table 3. The Most Interesting Topics in Communication among Farmers

\begin{tabular}{|c|c|c|c|c|}
\hline Topics & Extension Worker & Group Leader & Other Farmer & Credit Officer \\
\hline & \multicolumn{4}{|c|}{ 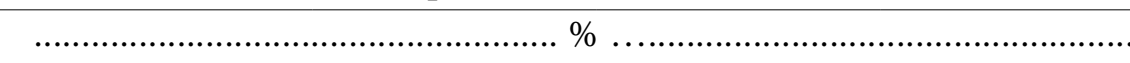 } \\
\hline Farm business & 10.0 & 12.0 & 4.5 & 66.6 \\
\hline Animal health & 30.0 & 4.0 & 18.2 & 0.0 \\
\hline Duck production & 0.0 & 0.0 & 22.9 & 11.1 \\
\hline Marketing & 10.0 & 56.0 & 18.2 & 11.1 \\
\hline Breeding & 10.0 & 8.0 & 4.5 & 0.0 \\
\hline Farm recording & 0.0 & 4.0 & 0.0 & 0.0 \\
\hline Credit & 20.0 & 0.0 & 4.5 & 11.1 \\
\hline Hatching & 20.0 & 16.0 & 18.2 & 0.1 \\
\hline
\end{tabular}

Communication problems aspects were: frequency being contacted by as well as actively contact to several persons, included extension worker,credit officer, group leader and other farmers. Result of concluded as follows:

Farmers were not actively comunicate but much more being approached and supervised by extension worker. Extension workers' information was more credible than others. Extension worker task as a government agent to help and support duck farmer.

Farmers were also passively communicated to group leader, because their information was less credible. Farmers' group task was to lead the farmer group meeting weekly.

There was some different ways of contacting among farmers. Farmers prefer to be contacted by other farmer rather than to actively contact. Therefore, farmers rarely communicate with one another in the case of duck farmer, consequently their experience are still remained low.

Credit officer became the most credible source of information in credit. Task of credit officer were either contacting or being contacted by farmer. Need of credit will be the reason they visit credit officer.

Participating in social organization becomes an important factor in improving the farmer motive to apply credit. Member of the organization was a mostly requirement to apply credit.

Farmer motive to request credit was quite related to those aspects of communication problems. Most interesting topics in communication among farmers are presented in
Table 3.

It was concluded that major topics were restricted to farm business, animal health, marketing, credit, and hatching. The most credible communication sources were extension worker and other farmer. Comparatively, communication was practiced among farmers. In any case the farmers were interested in credit information.

Several important items in this study were: 1) The younger farmer tended to be more motivated to request the credit than the elder farmer. Part timer farmers were more motivated than the full timer farmer. Larger farm sized farmer, more experienced, higher educated, and higher income, was more motivated in requesting credit; 2) The more often farmer to be visited by extension worker and credit officer, and more active participating in social organization, the higher motivated to request credit. The more frequent farmer visited the extension worker, and to be visited by both group leader and other farmer, the higher motivated to request credit. However, the more frequent they visited group leader and other farmer, the less motivated to request credit, 3) The higher educated farmer, more frequent to communicate with extension worker and other farmer. The higher income farmer, more frequent to communicate with either extension worker or credit officer, and most of them were actively participating in social organization.

\section{CONCLUSION}

Farmer motivation in requesting duck farm 
credit was affected by their characteristics, mainly: educational level, income, and age. Higher motivated farmer in requesting duck farm credit were the more frequent to communicate with either extension worker or credit officer, and participating in social organization as communication problems aspects. Increasing farmer motivation to request the farm credit can be increased through communication activities, either formal or informal.

\section{ACKNOWLEDGMENTS}

The authors thank Ms Eva Suhanti for helping in collecting data. The authors also thank to Overseas Business Cooperation Fund of Japan for supporting fund of this study.

\section{REFERENCES}

Burgoon, J.K., and B.A. LePoire. 1993. Effects of communication expectancies, actual communication and expectancy disconfirmation on evaluation of communication and their communication behavior. Human Commutations Research 20:67-96

Cronbach, L.J. 1951. Coefficient alpha and the internal structure of tests. J. Psychometrical $16: 297-334$

Haris, T.E., and M.D. Nelson. 2008. Applied Organizational Communication. LEA Publisher. New York.
Kamhawi, R., and D. Weaver. 2003. Mass communication research trends from 1980 to 1999. J. Mass Communication Quarterly 89:7-27

Lakin, N., and V. Schaubel. 2010. Corporate Community Involvement. Greenleaf Publishing. Stanford, California.

Leary, M.R., J. Twenge and E. Quinlivan. 2006. Interpersonal rejection as a determinant of anger and aggression. Personality and Social Psychology Review. 10:111-132.

Lee, B.K. 2005. Crisis, Culture, Community. Communication Yearbook. P.275-309.

Leeuwis, C. 2004. Communication for Rural Innovation: Rethinking Agricultural Extension. $3^{\text {rd }}$ Edition. Blackwell Publishing Ltd. Victoria, Australia.

Lindner, J.R., T.H. Murphy and G.E. Briers. 2001. Handling nonresponse in social science research. J. Agric. Education 42(4):43-53.

Ministry of Agriculture. 2006. 100 Year Agriculture in Progress. Jakarta. Indonesia.

Oakley, P. 1988. Extension and technological transfer: The need for an alternative. J. Hort. Sci.23(3):98-99

Shah, J.Y. and W.L. Gardner. 2008. Handbook of Motivation Science. The Guilford Press. New York.

van den Ban, A.W. 1988. Agricultural development: Opportunities and threats for farmers and implications for extension organizations. J. Agricultural and Extension Education. 6(3):145-156 